\title{
Environmental lobby splits on US tuna bills
}

Santa Cruz, California. US environmentalist groups are divided over two Senate bills designed to soften the current prohibition on the import of tuna caught using a controversial method that at one point led to the death of 350,000 dolphins a year. At issue is whether it is justified to save one species, albeit one widely embraced by the public, at the risk of endangering other species with less passionate advocates.

One bill, supported by groups including Greenpeace, the World Wildlife Federation and the Environmental Defense Fund, would relax the restrictions on tuna caught using purse-seine methods, providing the methods are modified to result in fewer dolphin deaths. This bill has been introduced by Ted Stevens (Republican, Alaska) and John Breaux (Democrat, Louisiana).

The second bill, sponsored by Barbara Boxer (Democrat, California.) and Joseph Biden Jr (Democrat, Delaware), would change the rules to allow a country to sell its tuna to the United States provided the fish were not caught using any type of purseseine method. Since 1994 the United States has banned all tuna imports from a country if any of its boats use purse-seine nets.

This bill is supported by organizations that include the Sierra Club, the Humane Society of the United States and the Earth Island Institute, which vociferously object to the Stevens-Breaux bill on the grounds that even the modified purse-seine methods cause discomfort to dolphins.

Pressure to change the current legislation, one of the most popular environmental laws ever passed, comes both from Latin American countries whose tuna is covered by the embargo, and from officials who are responsible for administering the General Agreement on Tariffs and Trade (GATT), on the grounds that this agreement is violated by the American ban.

\section{South Africa sets out science options}

Cape Town. The South African government last week published a long-awaited consultation paper on science and technology which acknowledges that a crisis is confronting the research sector. It suggests various ways in which the country's research administration might be made more effective - but still leaves open the question of which solutions should eventually be adopted.

The green paper was launched in Pretoria by the Minister of Arts, Culture, Science and Technology, Ben Ngubane, who said that it would form the basis of a new science and technology system. Scientists and other interested parties have been invited to comment by the end of February.

Spending on research and development (R\&D) in South Africa has declined from a high point of 1.04 per cent of gross domestic product (GDP) in 1987 to 0.68 per cent last year. This fall largely reflects a decline in military expenditure, without comparable funds being reinvested in the civil sector.

The green paper emphasizes that the country's emerging democracy needs to be founded on economic growth. Ngubane has promised to champion the cause of $R \& D$ within the government of national unity, despite its many other short-term priorities.

Various options for the government funding of $\mathrm{R} \& \mathrm{D}$ are considered. At present, for example, funding is allocated annually; but the report suggests that it might be done every two or even four years, a proposal that was put forward by Bernie Fanaroff, the senior civil servant who is responsible for the government's reconstruction and development programme (see Nature 374, $665 ; 1995)$.

The paper also considers how research funding should be coordinated. The funding of the seven research councils whose budgets make up the science vote is at present coordinated by the department. But the funds are awarded to them through five different ministries, after a cabinet committee has decided on the final allocation of funds between the councils.

The green paper suggests, too, ways of separating out responsibility among the councils for the agency function of awarding research grants and carrying out in-house research. Three of the councils at present carry out both functions, whereas the other four are primarily concerned with in-house research. But the paper does not address the question of whether a clear demarcation of responsibilities for the two categories of funds would lead to a higher proportion being allocated to the academic sector, which has in the past received a relatively low proportion of science funding by international standards (see Nature 356, 9; 1992).

In addition, the paper raises the possibility of increasing the scope of the R834million (US\$230-million) science vote to include the research budgets of the Defence Ministry (R550 million) and the Atomic Energy Corporation (R120 million). Such a move would allow the funds to be reallocated in line with national goals. There is widespread feeling both within the scientific community and within government that these allocations are a hangover from the previous regime.

The green paper will be followed later this year by a whitc paper outlining the government's position on science and technology, including a clearly defined role for the ministry.

Michael Cherry
Fishermen use purse-seine methods to take advantage of an unexplained phenomenon in which mature tuna swim beneath schools of dolphins. This happens in particular in the eastern tropical Pacific (ETP) fisheries, which spread from California to Hawaii and south to Chile.

Fishermen hunt for tuna by looking for dolphins near the surface. A likely catch is then surrounded, using motor boats, and a large fishing boat pulls in a net containing both dolphins and tuna. The tuna are kept, but the dolphins are killed and dumped overboard. Other dolphins that get caught in the net may also drown in the process.

The US embargo on purse-seine tuna has forced many fishing fleets to leave the ETP

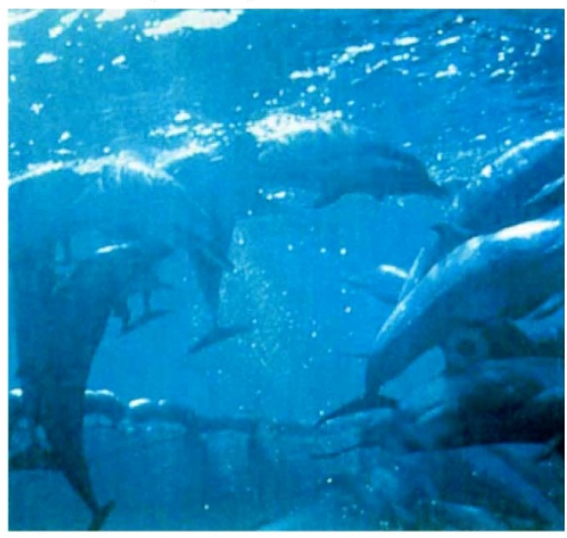

Tangled up: dolphins are not the only ones to be caught up in a web of confusion.

for other parts of the ocean. Tinned tuna sold in the United States with the label 'dolphin safe' comes either from free-swimming schools or from fish that gather underneath floating objects, known as 'log sets'.

But many scientists point out that both of these fishing methods themselves result in the deaths of other species, including some that are more endangered than dolphins. The 'by-catch' from school and log set fishing includes sea turtles and sharks, while juvenilc tuna can also be killed.

A fishing method known as 'backing down' has recently been developed in which purse-seine nets are tilted down at one end to let the dolphins escape, reducing mortality to fewer than 4,000 a year.

The Stevens-Breaux bill would allow this method and permit tuna to be labelled 'dolphin safe' as long as an observer on each fishing boat saw no dolphins die. But Naomi Rose of the Humane Society of the United States says many dolphins are injured or killed without being seen from the boats.

Niaz Dorry of Greenpeace says the 'dolphin safe' label is a misnomer, as only 20 per cent of the world's tuna are caught in the ETP, and dolphins are still killed when fishermen pursue the other 80 per cent. Reducing by-catch would protect diminishing food fish resources, she says.

Joel N. Shurkin 